\title{
2: $217323633-217354662$
}

National Cancer Institute

\section{Source}

National Cancer Institute. 2:217323633-217354662. NCI Thesaurus. Code C42521.

Physical location of IGFBP2_Gene 